\title{
Aikuiskasvatuksen monimuoto-opetus täydennyskoulutuksen kokeiluna
}

Tampereen yliopiston aikuis- ja nuorisokasvatuksen laitos on yhteistyössä täydennyskoulutuskeskuksen kanssa pannut alulle kokeilun, jonka tarkoituksena on parantaa aikuiskoulutustehtävissä jo toimivien mahdollisuuksia suorittaa aikuiskasvatuksen approbaturia vastaava opintokokonaisuus osana ammatillista täydennyskoulutustaan. Kokeiluohjelmassa yhdistetään ohjattu itseopiskelu useanmuotoiseen lähiopetukseen, vähennetään opintojen sidonnaisuutta yliopiston luento-opetukseen, lisätään opetuksen käytännönläheisyyttä ja parannetaan opetuksen alueellista tavoitettavuutta.

\section{Kahden projektin kautta kolmanteen}

Tätä projektia, jonka suunnittelu alkoi vuonna 1988, edelsi parikin vastaavanlaista hanketta. Jo 1970-luvun lopulla kehiteltiin ensisijaisesti kansalaisopistojen opettajia varten erityisohjelma. Se poikkesi tavanomaisesta avoimen korkeakoulun opetuksesta ennen muuta siten, että tietty osa silloisesta approbaturista voitiin korvata kansalaisopistojen yhteisen opetussuunnitelman mukaan järjestämillä didaktisilla kursseilla. Tätä hanketta olivat lai- toksen kanssa aktiivisesti suunnittelemassa ja toteuttamassa kouluhallitus ja Kansalais- ja työväenopistojen liitto.

Molemmat osallistuivat myös nyt käynnissä olevan kokeilun alkusuunnitteluun.

Toinen aikaisempi hanke toteutettiin yhteistyössä Helsingin ja Jyväskylän yliopistojen sekä Yleisradion kanssa. Siinä aikuiskasvatuksen approbaturin suorittaminen rakentui kokonaan ohjatulle itseopiskelulle, jota varten toimitettiin kolme uutta oppikirjaa ja muuta oppimateriaalia. Yleisradio,lähetti pariinkin otteeseen sarjan ohjelmia, jotka täydensivät kirjallista materiaalia ja sisälsivät opinto-ohjausta. Aikuisopintojen tutkintotoimikunta organisoi maan eri puolilla toimeenpannut tenttitilaisuudet.

Parhaillaan toteutettava kokeilu perustuu siten aikaisemmille kokemuksille ja on välitöntä jatkoa 70-luvun lopussa alkuun pannulle hankkeelle. Kokonaissuunnitelma on nyt kuitenkin perusteellisesti uudistettu niin sisällöllisesti kuin menetelmällisestikin. Radioprojektin tapaan nyt kokeillaan, vaikkakin toistaiseksi suppeammin, ohjatun itseopiskelun ja lähiopetuksen yhdistelmää. Uutta on myös se, että ohjel- 
ma on alun perin suunniteltu kaikille, niin ammatillisen kuin yleissivistävänkin aikuiskoulutuksen opettajina tai muissa kouluttajatehtävissä toimiville.

Kokeilun varsinainen toteuttava suunnittelu alkoi vuonna 1989 opetusministeriön rahoituksen turvin. Määrärahalla palkattiin projektille päätoiminen suunnittelija ja kustannettiin oppimateriaalin valmistaminen. Vuonna 1990 rahoitus supistui, mutta sillä määrärahalla, jonka täydennyskoulutuskeskus osoitti projektille opetusministeriön myöntämästä kokonaissummasta, saatettiin edelleen palkata projektille päätoiminen suunnittelija keväästä vuoden loppuun. Suunnittelijana toimii tällä hetkellä Taina Törmä ja kokeilun johtajana professori Aulis Alanen. Suunnitelmaa toteuttava opetus alkoi kuluvan vuoden kevätlukukaudella.

\section{Vaihtoehtoinen ohjelma}

Kokeilun erityisjärjestelyissä ovat keskeisessä asemassa ne vaihtoehtoiset sisällöt ja opintomuodot, joilla aikuiskasvatuksen alin opintokokonaisuus (approbatur) voidaan suorittaa. Tampereen yliopiston nykyisten vaatimusten mukaan tämä 15 opintoviikon kokonaisuus koostuu viidestä kolmen opintoviikon mittaisesta opintojaksosta, jotka ovat Johdatus aikuiskasvatukseen, Aikuiskasvatuksen psykologia, Aikuisdidaktiikka, Kasvatustieteen tutkimus I ja Kirjatentti I. Kokeiluohjelmassa opiskelijat voivat suorittaa kaksi jaksoa vaihtoehtoisella tavalla:

Opintojakso Johdatus aikuiskasvatukseen voidaan suorittaa ohjattuna itseopiskeluna kirjallisen oppimateriaalin varassa.

- Aikuisdidaktiikan kurssi voidaan korvata kansalaisopistoissa tai muissa aikuisoppilaitoksissa järjestettävällä, tähän tarkoitukseen suunnitellulla aikuisopetuksen peruskurssilla. Kurs$\sin 50$ opetustuntia jakautuu teoriaopintoihin ja praktikumin luonteiseen harjoituskurssiin ryhmäkeskusteluineen ja arviointeineen. Kehykset opetukselle antaa erityinen mallisuunnitelma. Kurssin opettajat hyväksyy ao. oppilaitoksen esityksen perusteella projektin johto ja perusvaatimukseksi on asetettu noin 35 opintoviikon mittaiset aikuiskasvatuksen opinnot (cum laude approbatur) tai vastaavat tiedot.

\section{Suunnitelman tähänastinen toteuttaminen}

Opetus alkoi aikuisopetuksen peruskurssilla, joka kevätlukukaudella 1990 järjestettiin 15 kansalaisopistossa. Eteläisin paikkakunta oli Järvenpää ja pohjoisin Hyrynsalmi. Opiskelijoita ilmoittautui yhteensä 238 (naisia 201, miehiä 37). Kurssin suoritti hyväksytysti 191; keskeyttäneitä oli 47. Opintokokonaisuuden muiden jaksojen suorittamiseen on tänä vuonna mahdollisuus viidessä kesäyliopistossa. Koska kokeilun ensimmäinen kierros on tätä kirjoitettaessa vielä kesken, ei kokeiluryhmien opintojen jatkumisesta vielä voida esittää tarkkoja tietoja. Huomattava osa kevätlukukaudella aloittaneista on kuitenkin jo tähän mennessä saanut opintokokonaisuuden suoritetuksi.

Tähänastisten ilmoittautumisten mukaan aikuisopetuksen peruskurssin järjestää työkaudella 1990-1991 ainakin 27 kansalaisopistoa maan eri puolilla ja lisäksi Ammattikasvatushallinnon koulutuskeskus Tampereella. Kokeilupisteiden määrä saattaa vielä jonkin verran kasvaa. Opintokokonaisuuden täydentävää laitoksen avointa opetusta järjestetään alustavan päätöksen mukaan vuonna 1991 neljässä kesäyliopistossa sekä talvikautena Tampereella suoraan täydennyskoulutuskeskuksen organisoimana.

\section{Kehittämisen näkymät}

Hankkeen jatkuminen, mahdollinen laajentuminen ja vakiintuminen kokeilusta yliopiston kiinteäksi toimintamuodoksi on kiinni rahoituksesta, jonka järjestyminen on tällä hetkellä vielä avoinna. Perusedellytys toiminnan jatkumiselle ainakin nykyisessä laajuudessaan on mahdollisuus projektisuunnittelijan jatkuvaan palkkaamiseen. Rahoitusta tarvittaisiin myös sekä opimateriaalin jatkuvaan kehittämiseen että seurantatutkimukseen. Toiminnan laajentamisen tarve on kysynnän perusteella joka tapauksessa ilmeinen.

Alkuperäisen suunnitelman mukaan ohjatun itseopiskelun osuutta lisättäisiin saatujen kokemusten mukaan (lähinnä tulisi kysymykseen aikuiskasvatuksen psykologian opintojakso) ja uusien teknologisten välineiden käyttöä kehiteltäisiin monimuoto-opetuksen olennaisena osana. Tähänastiset kokemukset rohkaisevat hankkeen jatkamiseen.

Projektia koskeviin tiedusteluihin vastaa suunnittelija Taina Törmä (puh. 931157 192). 